\title{
SELF-DETERMINATION AT THE BEGINNING OF 1918 AND THE GERMAN REACTION
}

\author{
Christian Rust
}

Abstract This paper examines the role of the principle of self-determination in German diplomacy and domestic debate until a peace treaty between the Central Powers and Russia was concluded in March 1918. We will first look at the position of the German government and of the Supreme Command. Thereafter we analyse the role of self-determination as expressed in the peace proposals by President Wilson and Lloyd George, both of them reacting to the Soviet initiative and challenging the German position. In the end the focus is directed to the Reichstag parties, especially the Reichstag majority, and their understanding of self-determination.

Following the Bolshevik seizure of power in November 1917, the idea of self-determination became extraordinarily significant in international relations during the last year of World War One. The Central Powers accepted the Soviet peace proposal of 'a democratic peace without annexations and contributions on the basis of the right of the peoples to self-determination'. 1 On these grounds, the armistice and peace negotiations began in Brest-Litovsk in December 1917. The Allied and Associated Powers remained absent.

${ }^{1}$ Trotsky to Ambassador, November 7 (21), 1917, in: Ambassador in Russia (Francis) to the Secretary of State, Foreign Relations of the United States (hereafter - FRUS) 1918, Russia, I (Washington, 1919), p. 244; Decree on Peace approved by the Second Whole Russian Soviet Congress, October 26 (November 8), 1917, Deutsch-sowjetische Beziehungen von den Verhandlungen in Brest-Litowsk bis zum Abschlu $\beta$ des Rapallovertrages (hereafter - DSB), I: 1917-1918 (Berlin (DDR), 1967), Doc. 1, pp. 25-28; Lenin and Trotsky 'To the peoples of the belligerent countries', November 15 (28), 1917, in: Lersner to German Foreign Office, November 28, 1917, Der Friede von Brest-Litowsk (hereafter - FBL), ed. W. Hahlweg (Düsseldorf, 1971), Doc. 10, pp. 28-30. Although not part of the Soviet November initiative, the right to secession from an existing State was expressedly approved by the Bolsheviks, see J. Stalin, 'Marxism and national question' (1913), Werke, II (Berlin, 1953); and Lenin's theses of April 7, 1917, according to P. Kluke, Selbstbestimmung. Vom Weg einer Idee durch die Geschichte (Göttingen, 1963), pp. 53-55. The Soviet understanding of self-determination is analysed in G. Decker, Das Selbstbestimmungsrecht der Nationen (Göttingen, 1955), pp. 151-170. 
This paper examines the role of the principle of self-determination in German diplomacy and domestic debate until a peace treaty between the Central Powers and Russia was concluded in March 1918. We will first look at the position of the German government and of the Supreme Command. Thereafter we analyse the role of self-determination as expressed in the peace proposals by President Wilson and Lloyd George, both of them reacting to the Soviet initiative and challenging the German position. In the end the focus is directed to the Reichstag parties, especially the Reichstag majority, and their understanding of self-determination.

\section{The Imperial German Government, the Supreme Command and} Self-determination until January 1918 The new German imperial chancellor, Count Hertling called the Soviet peace proposals worth discussing. On November 29, 1917, he declared in the Reichstag:

As regards the countries of Poland, Lithuania and Courland, which were formerly under the sovereignty of the tsar, we consider that the people living in those countries have the right to determine their own fate. We expect that they will adopt the system of government best suited to their conditions and culture. ${ }^{2}$

Hertling's speech triggered a debate in Germany about the role of self-determination in German Eastern policy. The government was challenged by the Supreme Command on the one hand, and by the Reichstag majority on the other hand. The Social Democrats, the left liberal Progressives and the Catholic Centre Party had demanded Hertling's public reference to self-determination as a condition to support his foreign policy. ${ }^{3}$

${ }^{2}$ Address by Chancellor Hertling, Reichstag, session 127, November 29, 1917 , Verhandlungen des Reichstags [VR], Vol. 311, Stenographische Berichte (Berlin, 1918), p. 3947. The German original reads: 'Was die <...> Länder Polen, Kurland, Litauen betrifft, so achten wir das Selbstbestimmungsrecht ihrer Völker.' English text in J.B. Scott, Official Statements of War Aims and Peace Proposals, December 1916 to November 1918 (Washington, 1921), p. 192.

The under-secretary of state, von dem Bussche, stated in a memorandum for the Foreign Office on December 3, 1917: 'We are prepared to conclude a peace without annexations by violence and without contributions and on the grounds of the right of nations to self-determination.' 'Guidelines for a separate peace with Russia', FBL, Doc. 21, p. 38.

${ }^{3}$ Meeting of the chancellor with the representatives of the Reichstag parties, November 28, 1917, Der Interfraktionelle Ausschuss 1917/1918 [hereafter - IA], I, ed. E. Matthias (Düsseldorf, 1959), Doc. 125, pp. 620-622.

Kühlmann to Hertling, January 11, 1918, Das Werk des Untersuchungsausschusses der Verfassungsgebenden Deutschen Nationalversammlung und des 
Hertling, however, and his secretary of state, Richard von Kühlmann, were not advocating a policy of self-determination because they really believed in it. They wanted peace in the East, but they wished to preserve Germany's power and influence, though not by means of annexation. The Reichstag majority was not to be alienated, and later 'tolerable relations' with Russia should be possible. ${ }^{4}$

On the contrary, the German military chiefs, Paul von Hindenburg and Erich Ludendorff sought to establish an Eastern Empire by pushing Russia far east and joining the Western border states to the German Empire. In April 1917, the following result of a meeting with Kaiser Wilhelm II was written down: 'Courland and Lithuania are to be won for the German Empire'. 5 By August 1917, this policy had been adopted by Kaiser Wilhelm II and the government of Chancellor Michaelis. Courland was planned to be a duchy, Lithuania a grand principality. The 'form of their connection' to the German Empire was left open while the Supreme Command demanded a personal union with the Kaiser. ${ }^{6}$ Already in the end of July 1917, Ludendorff had instructed the chiefs of military government in Lithuania and Courland, Isenburg and Gossler, to create a pro-German Council (Vertrauensrat) in order to secure a vote of the population asking for German 'protection'. ${ }^{7}$ Ludendorff bluntly informed the German Foreign Office in August 1917, 'after Poland has been taken away from me..., I need to create another kingdom in Lithuania and Courland for me'. ${ }^{8}$

While the so-called Austrian-Polish concept was rejected in the meeting at Kreuznach on August 9, 1917, Poland was planned to be connected to Germany. In case this became impossible, a fourth

Deutschen Reichstages 1919-1926 [hereafter - WUA], series IV: Die Ursachen des deutschen Zusammenbruchs im Jahre 1918, 2 (Berlin, 1925), Doc. 4, pp. 130-134, quotation p. 131.

${ }^{4}$ Hertling to Kaiser Wilhelm II, January 23, 1918, WUA IV, 2, pp. 59-68, quotation p. 65.

${ }^{5}$ Note on the Meeting at Kreuznach, April 23, 1917, WUA IV, 12/2 (Berlin 1929), attachment 14, pp. 200-201.

${ }^{6}$ Result of the Meeting between the Imperial Chancellor and the Supreme Command, Kreuznach, August 9, 1917, WUA IV, 12/2, p. 204.

${ }^{7}$ Conference in Bingen, July 31, 1917, according to G. Ritter, Staatskunst und Kriegshandwerk. Das Problem des 'Militarismus' in Deutschland, III (Munich, 1964), pp. 98-99. The author speaks of the 'theatre of the founding of a State'.

${ }^{8}$ Ludendorff to the Under Secretary of State, Zimmermann, end of August 1918, Ritter, Staatskunst, III, p. 603, note 65. 
partition of Poland was considered. Later in the year of 1917, the new chancellor, Hertling and the Kaiser came to favour the AustrianPolish solution. However, the government rejected the annexion of Polish territory to Germany, because it was opposed to incorporate more of the Polish population. ${ }^{9}$ This was an argument rather in favour of the principle of nationality and not of self-determination. Unmoved by such considerations, the Supreme Command demanded a Polish 'buffer strip' and thus provoked serious conflicts with the governments in Berlin and in Vienna. ${ }^{10}$

Prior to the peace negotiations at Brest-Litovsk the military chiefs vigorously opposed the principle of self-determination. For instance, they did not consent to the striving of the Lithuanian Taryba for an independent state and a national assembly. ${ }^{11}$ They intended to maintain the military administration and occupation for years to come. ${ }^{12}$ Hindenburg demanded that Estonia and Livonia also be bound to Germany. Both provinces were - apart from Riga and the Gulf islands - not yet occupied by German troups.

Kaiser Wilhelm II, more reluctant, decided that during the peace negotiations the evacuation of Russian troups from Estonia and

${ }^{9}$ Hertling to Kaiser Wilhelm, January 23, 1918, WUA IV, Vol. 2, pp. 59-68, quotation p. 61. Internally, the Supreme Command reacted as follows: 'We must avoid the incorporation of an alien population by German colonisation'. Note by the Supreme Command, reacting to a memorandum by Hertling to the Kaiser (January 23, 1918), quoted by Schwertfeger, WUA IV, 2, p. 62, note p. 44. Kühlmann, like Hertling, favoured the Austrian-Polish solution, because he laid great emphasis on the relations with Vienna. The Kaiser adopted this position in the Crown Council on November 5, 1917; see W. Conze, Polnische Nation und Deutsche Politik im Ersten Weltkrieg (Cologne, 1958), p. $326 \mathrm{ff}$.

${ }^{10}$ Ibid., pp. 323-324, 327-333, on the conflict between Berlin and Vienna, respectively between the German Supreme Command and Austria-Hungary, about the Polish 'buffer strip' in November and December 1917.

${ }^{11}$ Hindenburg to Hertling, December 4, 1917, FBL, Doc. 29, pp. 57-59; Prof. Bredt, Der deutsche Reichstag im Weltkriege, WUA IV, 8, Berlin 1926, p. 333. Cf. G. Ritter, Staatskunst, IV (Munich, 1968), pp. 107-108; G. Linde, Die deutsche Politik in Litauen im Ersten Weltkrieg (Wiesbaden, 1965), pp. 94-110. Ludendorff stressed in his memoirs, 'the slogans of a peace without annexation and of the self-determination of the small nations suited to solve the Lithuanian question in contradiction to German interests'. E. Ludendorff, Meine Kriegserinnerungen (Berlin, 1919), p. 376. Cf. Linde, Die deutsche Politik, pp. 108-109, following Petras Klimas, Der Werdegang des litauischen Staates von 1915 bis zur Bildung der provisorischen Regierung im November 1918 (o. O. 1919). Cf. J. Lee, The Warlords. Hindenburg and Ludendorff (London, 2005), here p. $145 \mathrm{ff}$.

${ }^{12}$ Meeting of the Imperial Government and the Supreme Command, December 7, 1917, FBL, Doc. 41, p. 77. 
Livonia should be proposed, but not demanded, 'in order to let Estonians and Livonians exercise their right to self-determination'. Certainly, self-determination here merely meant separation from Russia. As for Lithuania and Courland, the Kaiser's plans to rule them sounded more liberal than the rigorous position of the Supreme Command. ${ }^{13}$

Ludendorff, dreaming of lebensraum in the East, tried in the most absurd way to press his annexionist programme into the words of self-determination: the latter should be respected by means of clearing Finland, Estonia and Livonia of Russian troups. Moreover: 'It is our interest to respect the ethnic claims of Lithuanians and Courlanders by the way of connecting them' to Germany. ${ }^{14}$ Poland was supposed to be independent but tightly bound to the Central Powers.

While Chancellor Hertling, a tired man of 74 years, did not show much political initiative, Secretary of State Kühlmann was trying to reconcile the existing different positions as to self-determination. Kühlmann attempted to render the term self-determination diplomatically adaptable, interpreting it in Germany's interest. He explained to the Supreme Command his 'tactics of self-determination': It were decisive to obtain a declaration by the Western peoples of Russia that they wished to separate from Russia and strive to the West. The chancellor put it as follows: 'the willingness of the Lithuanians must be won'. ${ }^{15}$ Kühlmann affirmed, 'We must win the Lithuanians over to us' and insisted, 'not to offend the sensibility of the peoples who are to be connected to us'. ${ }^{16}$ 'The fiction of self-determination' was to be maintained by referring to the existing Land-Councils in the occupied territories: the Councils of Lithuania and Courland,

${ }^{13}$ Meeting in the General Headquarter of the Supreme Command, December 18, 1917, DSB, Doc. 40, p. 125.

${ }^{14}$ Guidelines by General Ludendorff for the peace negotiations with Russia, December 16, 1917, FBL, Doc. 80, p. 118. In this context, see Ludendorff's expression of the 'wall of German peoples against the Slavs', quoted by Ritter, Staatskunst, IV, p. 102.

${ }^{15}$ Meeting of the German Imperial Government and the Supreme Command, December 7, 1917, FBL, Doc. 41, p. 76.

${ }^{16}$ Note by Kühlmann, December 4, 1917, FBL, Doc. 25, p. 53. In his memoirs, Kühlmann admitted the instrumental use of the right to self-determination. The 'only practicable way' had been 'very narrow', between the Supreme Command, 'preferring blunt annexation', and the Reichstag majority being dedicated to 'a peace without annexations and contributions' R. von Kühlmann, Erinnerungen (Heidelberg, 1948), p. 523. 
established in September 1917, and the Regency Council of Poland, convened in October 1917. ${ }^{17}$

Kühlmann's diplomacy during the first phase of the peace negotiations at Brest-Litovsk was directed at achieving the Soviet recognition of these Councils and subsequently of the separation of the peoples concerned from the Russian Empire. ${ }^{18}$ Kühlmann intended to meet the Soviet demand for a plebiscite by referring it to a special commisson. Under pressure by the Supreme Command, however, Kühlmann rejected the evacuation of German troups demanded by Russia as being indispensable. ${ }^{19}$

On Christmas Day, when the Central Powers in Brest-Litovsk, called the Russian peace programme a 'basis for discussion', the Supreme Command aggressively opposed this. ${ }^{20}$ Although this declaration of the Central Powers was to come into effect only if the Entente joined the peace negotiations, Hindenburg was upset, 'that we have refrained from the acquisition of territory by force'. ${ }^{21}$

${ }^{17}$ Cf. Linde, Die deutsche Politik, p. 91 ff.; Conze, Polnische Nation, p. 299 ff.; H.-E. Volkmann, Die deutsche Baltikumpolitik zwischen Brest-Litowsk und Compiègne (Cologne-Vienna, 1970), p. $40 \mathrm{ff}$.

${ }^{18}$ See Kühlmann to Hertling, December 26, 1917, FBL, Doc. 109, p. 150-153. Kühlmann interpreted the Declaration by the Central Powers on December 25, not to strive for annexations by violence, in Germany's interest: the Allies had not refrained from 'an acquisition (in German Aneignung) or an inclusion (Angliederung) by contract of those territories that takes place on the grounds of self-determination being realized under our influence' (Kühlmann to Chancellor, December 26, 1917, DSB, Doc. 65, p. 202). Dealing with the peace negotiations: J.W. Wheeler-Bennett, Brest-Litovsk. The Forgotten Peace. March 1918 (1938; repr. London-New York, 1956); W. Hahlweg, Der Diktatfrieden von Brest-Litowsk 1918 und die bolschewistische Weltrevolution (Münster, 1960); W. Baumgart, 'BrestLitowsk und Versailles. Ein Vergleich zweier Friedensschlüsse', Karl Bosl (ed.), Versailles - St. Germain - Trianon (Munich, 1971), pp. 49-76.

${ }^{19}$ Kühlmann to Foreign Office, for the Chancellor, about the first plenary meeting (December 22, 1917), December 23, 1917, FBL, Doc. 97, pp. 133-134. The Soviet programme consisted of 1) the demobilisation of troops from the occupied territories, 2) a peace without annexations and contributions, 3) the re-establishment of full political autonomy for those territories that had lost it, 4) a referendum on the question of statehood and 5) the protection of minorities.

${ }^{20}$ Meeting of the peace conference, December 25, 1917, FBL, Doc. 106, p. 144, note 1. The peace proposals of the Central Powers also in: Consul General at Moscow (Sumners) to the Secretary of State, January 1, 1918, in: FRUS, 1918, Russia, I, pp. 410-411.

${ }^{21}$ Lersner to Hertling, December 26, 1917, DSB, Doc. 67, p. 203. 
Accordingly, the Supreme Command called upon the chancellor 'to speak the language of the victor' in Brest-Litovsk. ${ }^{22}$ The ultimative demands of the warlords resulted in a severe political conflict with the Hertling Government and the Kaiser. Although Hindenburg's threat to resign was not put into effect, the Supreme Command continued to call for control and subjugation instead of self-determination and liberty for the peoples of Eastern Europe.

\section{President Wilson, Lloyd George and Self-determination Shortly} prior to the second round of the peace negotiations in Brest-Litovsk, US-President Woodrow Wilson presented his Fourteen Points to the US Congress. Wilson not only intended to react to the Bolshevik peace plan, to keep the Russians from concluding a separate peace and to reunite the Allied and Associate Powers, he also was interested in winning the democratic and left parties in Germany for his own liberal peace project. ${ }^{23}$ Wilson asked if the German 'spokesmen' spoke for 'the Reichstag majority or for the military party'. Already in December 1917, Wilson had reproached the 'masters of German intrigue' with misusing the programme of 'no annexations, no contributions, no punitive indemnities' in order 'to lead the peoples of Russia astray'. ${ }^{24}$

The term of self-determination did not appear in the Fourteen Points. According to the American tradition, Wilson paraphrased it as the will of a nation 'to determine its own institutions'. ${ }^{25}$ In his famous 'peace without victory' speech in January 1917, the President

${ }^{22}$ Hindenburg to Hertling, January 9, 1918, DSB, Doc. 97, p. 270.

${ }^{23}$ This intention was stressed by the 'Inquiry', the 'think tank' providing the President and his special representative, Colonel House, with detailed information on European questions. In the memorandum 'The Present Situation: The War Aims and Peace Terms It Suggests', December 22, 1917, the authors Mezes, Miller and Lippmann recommended 'increased democratization of Germany <...> by representatives responsible to the German people' and 'the appointment to office of men...who vote Progressive, Centrist or Social Democrat tickets', in: The Papers of Woodrow Wilson, ed. A.S. Link, 45 (Princeton, 1984), p. 461. Cf. A.J. Mayer, Political Origins of the New Diplomacy, 1917-1918 (New York, 1959), pp. 329-367, especially pp. 333, 343, 352. See also K. Schwabe, Deutsche Revolution und Wilson-Frieden. Die amerikanische und deutsche Friedensstrategie zwischen Ideologie und Machtpolitik (Düsseldorf, 1971), pp. 29, 45 ff.

${ }^{24}$ Address to US-Congress, December 4, 1917, Scott, Official Statements, p. 195.

25 'The 14 Points Address', January 8, 1918, Wilson Papers, 45, pp. 537-538. According to the American tradition, 'nation' meant the 'community of all citizens entitled to vote' (Kluke, Selbstbestimmung, p. 63). 
had spoken of 'self-government' and 'government with the consent of the governed', meaning the fundament of democracy. ${ }^{26}$ Besides justice, liberty and reign of law, self-determination or self-government thus represented the key element in Wilson's peace project. ${ }^{27}$

In view of the national self-determination of a given national or ethnic group, leading to national independence, Wilson acted quite cautiously. The President advocated the 'principle of justice to all peoples and nationalities, $<\ldots>$ whether they be strong or weak'. ${ }^{28}$ He quite realized the revolutionary spirit of the principle of nationality, supposed to mean the framing of borders along ethnic aspects. Accordingly, Wilson told the British ambassador in Washington: 'In point of logic, pure logic, this principle which was good in itself would lead to the complete independence of various small nationalities now forming part of various empires. Pushed to its extreme this principle would mean the disruption of existing governments, to an undefinable extent'. ${ }^{29}$

Therefore, Wilson preferred to talk about peoples who 'should be allowed to live their own lives according to their own will and under their own laws'. In the Fourteen Points he used expressions like 'interests of the populations concerned' respecting colonial claims (point V), 'freest opportunity of autonomous development' concerning Austria-Hungary (X) and 'clearly recognizable lines of nationality' concerning the future borders of Italy (IX).

With respect to Poland, however, Wilson committed himself in the most far reaching way (XIII): 'An independent Polish state

${ }^{26}$ Address of President Wilson to the Senate, January 22, 1917, Scott, Official Statements, pp. 49-55, quotation p. 54. Cf. Wilson's famous expression in his 'War Message to Congress' on April 2, 1917: 'The world must be made safe for democracy'; Wilson Papers, 41 (Princeton, 1982), p. 525. US-Secretary of State Lansing noted, 'Self-determination' was a 'restatement' of the old thought of the 'consent of the governed'. R. Lansing, The Peace Negotiations (Boston-New York, 1921), p. 96.

27 Thus self-determination does not primarily relate to ethnic or territorial aspects, not primarily to a people or a State, as in the German understanding of the word, cf. G.E. Schmid, 'Selbstbestimmung 1919', Versailles - St. Germain Trianon, p. 129.

28 'The 14 Points Address', January 8, 1918, Wilson Papers, 45, p. 539.

${ }^{29}$ Wilson to ambassador Spring Rice, January 4, 1918, Wilson Papers, 45, p. 456. It is worth noting that the Secretary of State Lansing was extremely critical to the right to self-determination propagated by the Bolsheviks. Its overall application, he stated, would lead to nothing but 'international anarchy' and the complete destabilisation of 'social order'. Lansing to Wilson, January 2, 1918, FRUS, The Lansing Papers, II (Washington, 1940), p. 341. 
should be erected which should include the territories inhabited by indisputably Polish populations.' With a view to Russia, Wilson used rather vague words like 'evacuation of all Russian territory' and 'opportunity for the independent determination of her own political development and national policy' (VI). Wilson did not mention explicitly the future of the western peoples of the Russian empire. However, aiming at the negotiations at Brest-Litovsk, he called the 'treatment accorded to Russia by her sister nations in the months to come' the 'acid test of their goodwill'. ${ }^{30}$ Though, the demand for the evacuation of Russian territory did not answer the question, if the borderlands still belonged to Russian territory - a question that the German government would have answered with 'no'. ${ }^{31}$

Three days prior to the Fourteen Points, the British prime minister, Lloyd George had already committed himself to a territorial settlement 'based on the right of self-determination or the consent of the governed'. Lloyd George, like Wilson, regarded the principle of democracy as being expressed in both formulas. The London government now declared this principle to be the fundament of justice and 'permanent peace'. 32

However, the term was open to interpretation. For instance, a status of mere autonomy for the peoples of Austria-Hungary appeared to be compatible with self-determination. With respect to the Polish question, however, the prime minister clearly stressed the national and territorial aspect of self-determination. He committed himself to the construction of an independent Polish state 'comprising all those genuinely Polish elements who desire to form part of it'. On the other hand, it almost seemed that the British government had

30 'The 14 Points Address', January 8, 1918, Wilson Papers, 45, p. 537-538. The defensive tone with regard to Austria-Hungary was due to the fact that Wilson did not yet intend to dismember the Habsburg Empire; cf. his public commitment in his address to Congress on December 4, 1917 (Scott, Official Statements, p. 196).

${ }^{31}$ Mayer, Political Origins, p. 355, interprets this part of the speech in the way that 'Wilson refused to abandon Russia's borderlands to the mercy of the Central Powers'.

${ }^{32}$ Address of Lloyd George to Trade Union leaders, January 5, 1918, Scott, Official Statements, pp. 225-233, quotation pp. 228, 229. Cf. David Lloyd George, War Memoirs, V (London, 1936), pp. 53-62. Interestingly, Lloyd George always applied self-determination to the enemy countries or their colonies and never to the British Empire. To the background of Lloyd George's Speech see Mayer, Political Origins, pp. 313-328, and D. Woodward, 'The Origins and Intent of David Lloyd George's January 5 War Aims Speech', The Historian 34 (Nov. 1971), pp. 22-39. 
given up Russia. In case of a separate peace the premier saw the Western Russian provinces henceforth as 'a part of the dominions of Prussia'. ${ }^{33}$

\section{The Debate on Self-determination during the Second Round of} the Peace Negotiations at Brest-Litovsk Since the Allied and Associate Powers had not shown any interest in joining the peace negotiations, during the second phase of the Brest-Litovsk talks, beginning on January 9, a separate peace between the Central Powers and Russia was being negotiated. ${ }^{34}$ Secretary of State Kühlmann did not succeed in academically arguing with the new chairman of the Soviet delegation, Leo Trotsky, about self-determination and at the same time leading the Russians to renounce their western territories. ${ }^{35}$ Kühlmann's attempt to present the declarations of the Councils of Lithuania, Courland and Poland as legitimate and representative, utterly failed. ${ }^{36}$ Three days after Wilson's Fourteen Points Address, Trotsky reproached the German delegation in a rhetorically brilliant way for undermining completely the right to self-determination. Kühlmann countered with the ambiguous answer, the German delegation seriously wished 'to maintain the principle of the free right to self-determination of those nations in which we have a special interest'. ${ }^{37}$ The peace talks were about to fail. The Austrian-Hungarian secretary of state, Count Czernin, desperately striving for peace, in vain tried to mediate between Kühlmann and Trotsky. ${ }^{38}$

${ }^{33}$ Address of Lloyd George, January 5, 1918, Scott, Official Statements, p. 230.

${ }^{34}$ Kühlmann in the plenary session of the peace conference, January 9, 1918, $F B L$, Doc. 169 , p. 232. The second round of the peace negotiations lasted - with one interruption - from January 8 until February 9, when the peace treaty with Ukraine was concluded.

${ }^{35}$ Kühlmann, Erinnerungen, p. 524, admitted his plans 'to involve Trotsky in a pure academic discussion about the right of nations to self-determination and its practical application' and 'to achieve by the right of nations to self-determination what we actually needed in terms of territorial concessions'. Kühlmann explained to the Reichstag parties, it were self-evident 'that the incorporation (German: Anschluss) of these countries were without value' if it did not rest on the grounds of the majority of the population (January 23, 1918, IA 1917/1918, II, Doc. 147 a, pp. 136 ff., pp. 168-169, quotation p. 147).

${ }^{36}$ Commission on political and territorial questions, January 11, 1918, FBL, Doc. 176, p. 268.

${ }^{37}$ Ibid., Doc. 180, p. 282.

${ }^{38}$ Wheeler-Bennett, Brest-Litovsk, pp. 214 ff.; Lee, The Warlords, pp. 145-146. 
Kaiser Wilhelm II, who had backed the policy of Hertling and Kühlmann so far, now came closer to the strategy of the Supreme Command. The diplomatic tug-of-war about self-determination obviously annoyed the monarch. He noted, the Baltic countries were conquered by Germany and would fall under German influence: 'Liberal institutions will be given to each parts of the Baltic countries as soon as law and order have been established'. ${ }^{39}$ The Kaiser, furious at being told by the Russians about plebiscites, was moved by the Baltic-German nobility in Livonia and Estonia asking for help against the Bolsheviks. Shortly prior to the failing of the negotiations, the Kaiser ultimately told Kühlmann, Trotsky had to accept the German peace terms while giving up the Baltic countries as far as Narva - Pskov - Daugavpils inclusively 'without the right to self-determination etc.' ${ }^{40}$ The Kaiser only calmed down in the last minute on Hertling's initiative because Kühlmann threatened to resign.

It should at least be said in favour of the chancellor and his secretary of state, that as long as possible they held out against the annexion of Estonia and Livonia. ${ }^{41}$ However, Kühlmann's strategy failed to conclude a peace of negotiation on the grounds of the German interpretation of self-determination. Trotsky ended the peace negotiations on February 10 by 'refusing to sign a peace of annexation'. He declared: 'We are going out of the war, but we feel ourselves compelled to to refuse to sign the peace treaty. ${ }^{, 42}$

Two weeks earlier, responding to Wilson's Fourteen Points in the Main Committee of the Reichstag, Hertling had only agreed to the general points like open diplomacy, freedom of the seas, removal of economic barriers, limitation of armaments and league

${ }^{39}$ Note from Wilhelm II on a report by Kühlmann to Hertling on the meeting of the Commission on political and territorial questions, January 18, 1918, FBL, Doc. 224, note 15, p. 389. Cf. Ritter, Staatskunst, IV, p. 132.

${ }^{40}$ Cable from Wilhelm II to Kühlmann and General Hoffmann, February 9, 1918, FBL, Doc. 292, pp. 524-525; and Kühlmann to Hertling, February 10, 1918, ibid., Doc. 296, p. 529. Reply of the Kaiser in: Grünau to Kühlmann, February 10, 1918, ibid., Doc. 297, pp. 530-531.

${ }^{41}$ The Secretary of State did not want to risk the 'breach' with Russia over the question of the withdrawal of troops from Estonia and Livonia; he also wished to avoid the 'breaking up of the alliance' with Vienna; Kühlmann to Hertling, February $10,1918, F B L$, Doc. 295 , pp. 527-528.

${ }^{42}$ Commission on political and territorial questions, February 10, 1918, WheelerBennett, Brest-Litovsk, p. 227. German version: FBL, Doc. 301, p. 539. 
of nations. The chancellor wished to negotiate all of the territorial issues bilaterally, although he again spoke of the 'recognition of the right of self-determination' for the emerging nations in Western Russia. As for Poland, Hertling declared, the Central Powers had 'freed Poland from the tsarist regime which was oppressing her national individuality'. ${ }^{43}$

In short, with regard to the decisive territorial questions Berlin opposed the universal approach of Wilson's agenda. The chancellor of the German Empire, which was not yet governed by the consent of the governed, refused the President's leadership in defining selfdetermination. ${ }^{4}$

Unsurprisingly, Wilson accused the chancellor of bilateral diplomacy in the way of the Congress of Vienna. The President complained, Hertling wished to discuss "with no one but the representatives of Russia what disposition shall be made of the peoples and the lands of the Baltic provinces', 'and only with Austria what shall be done with Poland'. Wilson contrasted the peace resolution of the Reichstag to the policy of the German military party.

More clearly than ever before the President put down in words his understanding of self-determination: 'National aspirations must be respected; peoples may now be dominated and governed only by their own consent'. Here the American democratic tradition was combined with an ethnic-national aspect. Wilson's exclamation, 'Selfdetermination is not a mere phrase', but 'an imperative principle of action' certainly was directed against the misuse of this principle at Brest-Litovsk.

The President's striking criticism of the German autocracy led him to the four principles. He called for, 'that peoples and provinces are not to be bartered about from sovereignty to sovereignty as if they

${ }^{43}$ Main Committee (Hauptausschuss), January 24, 1918, Der Hauptausschuss des Deutschen Reichstags 1915-1918 [hereafter - HA], ed. R. Schiffers, M. Koch (Düsseldorf, 1983), IV, Doc. 205, pp. 1922-1924, literally in Schulthess' Europäischer Geschichtskalender, 1918/1 (Munich, 1922), pp. 19-25, and in Scott, Official Statements, pp. 246-254.

${ }^{44}$ Not until October 1918, when, under pressure by the Supreme Command, the new German government led by Prince Max of Baden asked for a peace on the grounds of the Fourteen Points, Wilson's peace project gained the outstanding importance for the international relations until the conclusion of the peace treaty of Versailles. Facing the German defeat, 'government and governed clinged to the Fourteen Points, seeking their salvation from the impending disaster'. K. Hildebrand, Das vergangene Reich. Deutsche Außenpolitik von Bismarck bis Hitler (Stuttgart, 1995), p. 376. 
were mere chattels and pawns in a game, even the great game, now forever discredited, of the balance of power'. He again demanded, 'that every territorial settlement in this war must be made in the interest and for the benefit of the populations concerned'. ${ }^{45}$

While German troups advanced in the direction of Petrograd, Hertling consented to the 'four principles' and declared it to be a 'chief objective $<\ldots>$ to create organs of self-determination' in Courland and Lithuania. The Germans did not intend 'to establish themselves in Esthonia or Livonia'. ${ }^{46}$ However, it was a provocation to declare the German Eastern policy to be compatible with Wilson's peace project. The British foreign secretary, Balfour immediately reproached the chancellor for 'lip service' concerning the 'four principles'. 47

In spite of their opposition to the 'military and annexionist party', as Wilson called it, ${ }^{48}$ Hertling and Kühlmann were not prepared to adopt a policy of liberation for the sake of the Eastern European peoples, as to settle their affairs with their consent and to establish really independent states. On every issue Berlin stayed behind the demands from London and Washington. This also applies to Poland, where the Regency Council at least met some of the demands with respect to self-determination.

After the peace negotiations had failed, the Supreme Command and the Kaiser put through their demand of a police action in the Baltic provinces including Estonia and Livonia. ${ }^{49}$ On 18 February,

${ }^{45}$ Address Delivered to a Joint Session of the Two Houses of Congress, February 11, 1918, Scott, Official Statements, pp. 265-271. K. Rabl, Das Selbstbestimmungsrecht der Völker (Cologne-Vienna, 1973), p. 59, sees Wilson's historical contribution to the term and the idea of self-determination in combining the 'principle of nationality' and the 'right to resistance on the one hand with the principle developed by the American Revolutionaries, that public power needs to be legitimated'. Cf. D. Heater, National Self-Determination. Woodrow Wilson and his Legacy (Basingstoke, 1994), pp. 1-52.

${ }^{46}$ Address by Hertling, February 25, 1918, Scott, pp. 279-285. Hertling added, 'in the frontier question only what is indispensable on military grounds will be demanded on Germany's part'. Original: VR, Vol. 311, pp. 4140-4141.

${ }^{47}$ Address by Balfour, February 27, 1918, Scott, Official Statements, p. 289.

${ }^{48}$ Wilson in his address in Baltimore, April 6, 1918, Scott, Official Statements, p. 310; here he also committed himself to the "principle of the free self-determination of nations', besides the 'ideals of justice and humanity and liberty' (p. 311).

${ }^{49}$ The decision was taken in the Crown Council in Homburg, including Kaiser Wilhelm II, the Government and the Supreme Command, February 13, 1918, DSB, Doc. 149 , p. $403-410$. 
the German army advanced in Russia; a few days later the Soviet government surrendered. Without further negotiation, the peace treaty of Brest-Litovsk was concluded on 3 March 1918. ${ }^{50}$

The Reichstag Parties and Self-determination Although the German Empire failed to be a parliamentary system, the influence and power of the Reichstag increased from summer 1917. The majority parties, comprising the majority Social Democrats, the left liberal Progressives and the Catholic Centre, had not been completely opposed to moderate annexions at the beginnning of the war. In the course of the war, however, all of these three parties gave up this option and adopted a policy of self-determination in the Eastern affairs. They set up a Reichstag resolution in July 1917, demanding 'peace and mutual understanding and reconciliation among the nations without forced acquisitions of territory'. ${ }^{51}$ The term selfdetermination, however, did not yet appear in this resolution. Since the Reichstag had to ratify a peace treaty, the Hertling government searched the approval of the majority parties of its Eastern policy.

The Conservative parties and the extreme right, while supporting a policy of military expansion, frankly opposed self-determination and the Fourteen Points. The conservative politician, Count Westarp tried in a quite absurd way to cover a policy of military expansion by the slogan of self-determination: 'Concerning Lithuania and Courland it may be possible to secure our borders under military aspects by the way of the right to self-determination. I especially doubt how to achieve this goal in Poland'. ${ }^{52}$ A member of the Deutsche Fraktion, Baron von Gamp-Massaunen, called the right to self-determination 'an extremely difficult thing'; his party was not at all bound to respect it. ${ }^{53}$ Wilson's Fourteen Points were bluntly rejected by the Conservatives. ${ }^{54}$ Outside the parliament, the extreme

${ }^{50}$ English Text of the Peace Treaty in: Consul General at Moscow (Sumners) to the Secretary of State, March 30 and April 2, 1918, FRUS, 1918, Russia, I, p. 437 ff.; German version in: DSB, Doc. 178, pp. 455 ff.

${ }^{51}$ Resolution on Peace Terms passed by the Reichstag, July 19, 1917, Scott, Official Statements, S. 114. Cf. T. Nipperdey, Deutsche Geschichte 1866-1918, II, p. 840 .

${ }^{52}$ Representatives of the Reichstag parties meeting with Kühlmann, January 1, 1918, IA 1917/1918, II, Doc. 130, p. 46.

${ }^{53}$ Speech by Baron von Gamp-Massaunen, representatives of the Reichstag parties meeting with Deputy Chancellor Count Roedern and Kühlmann, January 23, 1918, IA 1917/1918, II, Doc. 147 a, p. 160.

${ }^{54}$ Main Committee, January 24, 1918, HA, IV, Doc. 205, p. 1928. 
right, the All-Germans, joined together in the Vaterlandspartei under Tirpitz's leadership, agitated against 'the crazy slogan of the right of nations to self-determination'. 55

By contrast, the left wing Independent Social Democrats warned about reducing the principle of self-determination to a 'farce'. ${ }^{56}$ Their spokesman Hugo Hasse doubted the Councils of Lithuania and Courland were representative. He was convinced that a really free vote of the population would not lead to their connection to Germany. ${ }^{57}$

With regard to the international socialist movement, self-determination could be called a social democratic tradition. ${ }^{58}$ At the beginning of the war, some politicians of the right wing of the German Social Democratic Party were not opposed to moderate annexationist demands. ${ }^{59}$ This proved to be one reason for the splitting of the Social Democrats in a majority and an Independent Social Democratic party. Since April 1917, however, the majority Social Democrats definetely demanded a peace without annexations and contributions, on the basis of the right of nations to self-determination and national development. ${ }^{60}$ The peace should be concluded in agreement with the Reichstag resolution of July $1917 .{ }^{61}$ The motive of weakening

${ }^{55}$ According to the 'alldeutsche Blätter' quoted in Linde, Die deutsche Politik, p. 131 .

${ }^{56}$ Speech by Haase, representatives of the Reichstag parties meeting with Count Roedern and Kühlmann, January 23, 1918, IA 1917/1918, II, Doc. 147 a, pp. 157-158; speech by Haase, Main Committeee, January 26, 1918, HA, IV, Doc. 207, p. 1944.

${ }^{57}$ Representatives of the Reichstag parties meeting with Count Roedern and Kühlmann, January 23, 1918, IA 1917/1918, II, Doc. 147 a, p. 157-158.

${ }^{58}$ Rabl, Selbstbestimmungsrecht, pp. $55 \mathrm{ff}$. The First Socialist Internationale in 1865 had demanded for Poland 'the right to self-determination that belongs to every nation', ibid., p. 32.

${ }^{59}$ E.g. Gustav Noske with respect to Courland, E. Matthias, Die deutsche Sozialdemokratie und der Osten 1914-1945 (Tübingen, 1954), p. 9. Cf. Volkmann, Annexionsfragen, WUA IV, 12, pp. 58-66; and the remarks of the deputy Dittmann (former USPD) in WUA IV, 7, Berlin 1929, pp. $325 \mathrm{ff}$.

${ }^{60}$ Resolution of the Social Democratic Party, April 19, 1917, see Volkmann, Annexionsfragen, WUA IV, 12/2, pp. 128-129; Social Democratic Memorandum for the Stockholm Socialist Conference, June 12, 1917, Matthias, Sozialdemokratie und der Osten, pp. 16 ff. Cf. the speech by Ebert, representatives of the Reichstag parties meeting with Kühlmann, January 1, 1918, IA 1917/1918, II, Doc. 130, p. 47; Ebert in the Committee of the Reichstag Majority, January 23 1918, ibid., Doc. 146, p. 133.

${ }^{61}$ Meeting of Chancellor Hertling with representatives of all Reichstag parties, December 20, 1917, DSB, Doc. 45, p. 146. Scheidemann in the Committee of the 
Russia that was predominant in the Social Democratic policy of the Burgfrieden at the beginning of the war lost its importance. ${ }^{62}$

The leaders of the majority Social Democrats - Philipp Scheidemann, later first prime minister of the Weimar Republic, Friedrich Ebert, later first president of the Weimar Republic, and M. P. Eduard David wanted to realize the right to self-determination 'loyally', 'truely' 63 and 'in an unreserved way'. ${ }^{64}$ Two days prior to the presentation of Wilson's Fourteen Points, the Social Democrats in the Reichstag declared self-determination to be a democratic right and announced to oppose any misuse of this right to the ends of a hidden annexion. ${ }^{65}$

Ebert, Scheidemann and David did not regard the existing LandCouncils as representing the will of the peoples concerned. ${ }^{66}$ Scheidemann held the situation in Lithuania were 'extremely questionable', but everything else was 'direct lies'. In Courland it were necessary to insist on a 'real plebiscite'; no one except the nobility wanted to know anything of Germany'. ${ }^{67}$ How could the Land Councils, he asked, decide on so far reaching a step as separation from Russia? The Council in Courland mainly consisted of Germans. ${ }^{68}$

Reichstag Majority, January 4, 1918, IA 1917/1918, II, Doc. 133 a, p. 65; Scheidemann in a meeting of the Social Democrats in parliament, January 6, 1918, Die Reichstagsfraktion der deutschen Sozialdemokratie, 1898 bis 1918, ed. E. Matthias, E. Pikart, series II (Düsseldorf, 1966), Doc. 464 a, p. 357.

${ }^{62}$ Matthias, Sozialdemokratie und der Osten, p. 23.

${ }^{63}$ Speech by Dr David in the Committee of the Reichstag Majority, January 2, 1918, IA 1917/1918, II, Doc. 131 a, p. 55-56, quotation p. 55.

${ }^{64}$ Scheidemann in the Main Committee, January 5, 1918, HA, IV, Doc. 193 , p. 1844.

${ }^{65}$ Meeting of the Social Democrats in parliament, January 6, 1918, Reichstagsfraktion der Sozialdemokratie, 1898 bis 1918, II, Doc. 464 a, p. 358. In the party newspaper Vorwärts Scheidemann called for the fight against the 'politicians of conquest in our own country', FBL, Doc. 160, p. 220.

${ }^{66}$ Dr David, a pragmatic right wing Social Democrat, was prepared to accept the government in Poland. With respect to the Land Council in Lithuania, he saw at least a basis for further action. The situation in Latvia and Courland, on the other hand, he regarded to be most difficult. Speech by Dr David in the Committee of the Reichstag Majority, January 2, 1918, IA 1917/1918, II, Doc. 131a, pp. 55-56, quotation p. 55.

${ }^{67}$ Committee of the Reichstag Majority, January 2, 1918, IA 1917/1918, II, Doc. 131 a, p. 52.

${ }^{68}$ Representatives of the Reichstag parties meeting with Count Roedern and Kühlmann, January 23, 1918, ibid., Doc. 147 a, pp. 150-151. 
At the end of the process of self-determination the Social Democrats definitely wished a plebiscite to be held or a representative body to be elected in a democratic way. ${ }^{69}$ The party leaders mistrusted Kühlmann's diplomacy in Brest-Litovsk. Correctly, as it came to be proved, Scheidemann did not believe in Kühlmann's assertion that the Russian delegation in Brest-Litovsk were inclined to provisionally recognize the Land Councils. Ebert rejected the criticism of supporting the policy of the Bolsheviks by saying they were 'not engaged in terrorism'. ${ }^{70}$ Concerning Wilson's Fourteen Points, Scheidemann regarded an agreement on eleven of the Fourteen Points as soon being possible, only Alsace-Lorraine being indispensable. ${ }^{71}$

With respect to self-determination, the left liberal Progressive Peoples' Party adopted almost the same policy like the Social Democrats, though more pragmatic to some extent. ${ }^{72}$ The party leaders definetely opposed annexations and wished to back the German government against the Supreme Command. ${ }^{73}$ The deputy Fischbeck was prepared to accept the Land-Councils, however, he demanded to enlarge them and to summon a national assembly. ${ }^{74}$ The right of peoples to self-determination should be applied 'loyally'. ${ }^{75}$ Fischbeck

${ }^{69}$ Speech by Scheidemann, Representatives of the Reichstag parties meeting with Kühlmann, January 1, 1918, IA 1917/1918, II, Doc. 130, p. 34.

${ }^{70}$ Ebert meant the 'blowing up of the constituent body' in Petrograd by the Bolsheviks on January 19, 1918; Committee of the Reichstag Majority, January 23, 1918, IA 1917/1918, II, Doc. 146, p. 133. The Vorwärts wrote on February 15, 1918: 'What the Bolsheviks are doing in Russia is neither socialism nor democracy. It is rather a most violent putschism and anarchy. That is why we must make a clear distinction between the Bolsheviks and us.' Quoted in L. Stern (ed.), Die Auswirkungen der großen sozialistischen Oktoberrevolution auf Deutschland (Berlin, 1959), p. 142.

${ }^{71}$ Main Committee, January 26, 1918, HA, IV, Doc. 207, p. 1933; Scheidemann in the Committee of the Reichstag Majority, January 23, 1918, IA 1917/1918, II, Doc. 146, p. 129.

${ }^{72}$ Committee of the Reichstag Majority, January 16, 1918, IA 1917/1918, II, Doc. 141 a, p. 110.

${ }^{73}$ Fischbeck in the Committee of the Reichstag Majority, 8. 1. 1918, IA 1917/1918, II, Doc. 137, p. 83; Gothein in the Committee of the Reichstag Majority, January 16, 1918, ibid. Doc. 141 a, p. 100. Gothein in 1917 had made an unusual proposal to deal with the Eastern questions: an autonomous Polish-LithuanianCourlandian State should be constructed that would constitute a Bundesstaat within the German Empire (Linde, Die deutsche Politik, pp. 87-88).

${ }^{74}$ Meeting of representatives of the majoritarian parties with Count Roedern, January 18, 1918, IA 1917/1918, II, Doc. 143 a, p. 120.

${ }^{75}$ Naumann in the Committee of the Reichstag Majority, January 2, 1918, IA 1917/1918, II, Doc. 131a, p. 53. 
and his collegue Naumann agreed with Wilson's Fourteen Points, the only exception being Alsace-Lorraine. ${ }^{76}$

The leading politicians of the Catholic Centre Party committed themselves to the right to self-determination. However, they were interested in pragmatic solutions. Speaking for the Centre, Konstantin Fehrenbach, chairman of the important Main Committee of the Reichstag, chairman of the Committee of the Reichstag Majority and later prime minister of the Weimar Republic definitely opposed the intention of the Supreme Command to annex two million Poles and Lithuanians. Pointing to the danger of Russia being Germany's deadly enemy in the future, Fehrenbach was prepared to accept only small rectifications of borders. The peoples concerned should be allowed to choose their state system, monarchy or republic. ${ }^{77}$

The Centrist leader Matthias Erzberger, most busy in Polish and Lithuanian affairs, adopted a policy of self-determination in the course of the war. He had been one of the initiators of the peace resolution of the Reichstag in July $1917 .{ }^{78}$ Erzberger warned to interpret the right to self-determination but in Germany's favour. ${ }^{79}$ On his initiative, around the beginning of 1918, the Centre put forward to Chancellor Hertling the demand that the right to self-determination should also apply to the questions of statehood and of the head of state. ${ }^{80}$ Later in January, Erzberger regarded the peace proposals of President Wilson and Prime Minister Lloyd George as 'a basis for discussion', apart from Alsace-Lorraine. ${ }^{81}$

By a plan of six steps to deal with the emerging eastern nations, Erzberger attempted to reconcile the interests of the German Majority Parties, the German and the Soviet government. The main elements

${ }^{76}$ Main Committee, January 26, 1918, HA, IV, Doc. 207, pp. 1933, 1939.

${ }^{77}$ Fehrenbach in the Committee of the Reichstag Majority, January 8, 1918, IA 1917/1918, II, Doc. 137, p. 80: 'We do not want to force on them a king of Prussia as a grand duke of Lithuania and a duke of Courland.'

${ }^{78}$ Matthias Erzberger, Erlebnisse im Weltkrieg (Stuttgart/Berlin, 1920), pp. 251269. Cf. Volkmann, Annexionsfragen, WUA IV, 12/2, p. 67.

${ }^{79}$ Committee of the Reichstag Majority, January 2, 1918, IA 1917/1918, II, Doc. 131a, pp. 55-57, quotation p. 55.

${ }^{80}$ Erzberger, Erlebnisse, p. 188; Committee of the Reichstag Majority, Doc. $172 \mathrm{a}$, p. 317.

${ }^{81}$ Committee of the Reichstag Majority, January 23, 1918, IA 1917/1918, II, Doc. 146, p. 128-129. More reluctant with regard to the Fourteen Points was the Centre politician Trimborn, Main Committee, January 24, 1918, HA, IV, Doc. 205, p. 1923. 
of his plan comprised determining the borders between Russia and Germany, establishing the Land-Councils as provisional representative bodies and enlarging them if necessary. Then a decision should be made as to join the new state either to Russia or to the German Empire, alternatively establishing an independent state. Thereafter, the provisional representative bodies had to take over the administration. German demobilisation was planned to come into effect three months after the Russian withdrawal. In the end, a national representation should be constituted. ${ }^{82}$

The demobilisation of German troops proved to be the crucial problem. Consequently, Kühlmann regarded Erzberger's plan as in fact being 'useless': the German delegation, he said, 'had made concessions as far as the Supreme Command would agree to'. ${ }^{83}$ In other words, a rapid demobilisation was supposed to be impossible. Thus Erzberger's plan which appeared to be a feasible compromise, a way of organizing self-determination under the given circumstances, did not become part of the official German policy.

The politicians of the National Liberal Party mainly supported annexationist claims. ${ }^{84}$ The party leader Gustav Stresemann rejected the principle of self-determination as a means to settle Eastern affairs. Stresemann feared the demands of the Polish minority in Prussia for autonomy in the name of self-determination. If the principle of self-determination were recognized generally, but not with regard to Germany, it would turn against Germany, he said. ${ }^{85}$ Stresemann, the later Foreign Minister of the Republic of Weimar, regarded the Polish Question as the main problem of the ongoing peace negotiations. This he expected to be a cause for another world war. ${ }^{86}$

${ }^{82}$ Committee of the Reichstag Majority, January 2, 1918, IA 1917/1918, II, Doc. 131 a, pp. 55-57. Cf. Erzberger, Erlebnisse, pp. 242-243. Erzberger even got support for some points of his plan (not for demobilisation, however) by the Representative of the Supreme Command in Brest-Litovsk, General Hoffmann. Hoffmann, it is true, was prepared to accept 'the right to self-determination only as a means of separation of the peoples from Russia'. Yet Hoffmann's position was more moderate than that of his chief Ludendorff; this also goes for the Polish 'buffer strip'. Meeting of Erzberger and Generalmajor Hoffmann, January 2, 1918, IA 1917/1918, II, Doc. 132, pp. 61-62.

${ }^{83}$ Kühlmann to Hertling, January 19, 1918, FBL, Doc. 224, p. 390.

${ }^{84}$ Cf. Volkmann, Annexionsfragen, WUA IV, 12/2, p. 67.

${ }^{85}$ Committee of the Reichstag Majority, January 8, 1918, IA 1917/1918, II, Doc. 131, p. 58 .

${ }^{86}$ Meeting of the representatives of the Reichstag parties with Count Roedern and Kühlmann, January 23, 1918, IA 1917/1918, II, Doc. 147 a, p. 164. 
Moreover, Stresemann was extremely sceptical of Wilson's peace plan. ${ }^{87}$ It was a strange kind of realism and prophecy when Stresemann declared, he neither believed in permanent peace nor in Wilson's league of nations; it would 'burst like a soap-bubble' after the war. ${ }^{88}$ Erzberger rightfully criticized that the National Liberals were at the Supreme Command's service against Kühlmann. ${ }^{89}$

Not surprisingly, the Polish Reichstag deputies strongly criticized the peace treaty concluded with Ukraine in Brest-Litovsk on February 9, 1918. A member of parliament, Seyda, protested against the violation of the Polish right to self-determination. ${ }^{90}$ No Polish delegate had been invited to the peace negotiations, although the Regency Council and Prime Minister Kucharzewski had pressed for it, claiming the Polish right to self-determination. ${ }^{91}$ The German and Austrian-Hungarian delegations in Brest-Litovsk had promised the district of Cholm to the emerging state of Ukraine without even consulting any Polish politician. Following the conclusion of the peace treaty with Ukraine, Kucharzewski and his cabinet demissioned, and the Regency Council publicly protested against the violation of the right to self-determination. ${ }^{92}$

\section{The Reichstag Majority, the Peace Treaty of Brest-Litovsk and Self-} determination The German-Russian peace treaty of Brest-Litovsk was adopted by the Reichstag on March 22, 1918, by an overwhelming majority from the right to the centre, including the Centre Party and the Progressives. The Majority Social Democrats abstained from voting, the Independent Social Democrats rejected the peace treaty. Why did the Majority Parties, being so honestly committed to selfdetermination, not withhold their consent to the treaty?

\footnotetext{
${ }^{87}$ Main Committee, January 24, 1918, HA, IV, Doc. 205, pp. 1925-1926.

${ }^{88}$ Reichstag, 143. session, March 19, 1918, VR, Vol. 311, quotation pp. 4459,

${ }^{89}$ Committee of the Reichstag Majority, January 8, 1918, IA 1917/1918, II, Doc. 137 , p. 86.

${ }^{90}$ Main Committee, February 19, 1918, HA, IV, Doc. 207, p. 1954.

${ }^{91}$ Prime Minister Kucharzewski to Hertling, December 18, 1917, FBL, Doc. 90 , pp. 126-127; Kucharzewski to Kühlmann, January 2, 1918, ibid., Doc. 134, p. 190; Kucharzewski to Hertling and Kühlmann, January 17, 1918, ibid, Doc. 217, p. 371. By a visit paid to Berlin and Vienna in January 1918, Kucharzewski and the Regency Council did not have any success in being admitted as delegates to the peace negotiations; cf. Conze, Polnische Nation, pp. 337-340.

${ }^{92}$ On February 14, 1918, see Conze, Polnische Nation, pp. 340-342.
} 4460. 
At the end of February 1918 Erzberger even called for the peace treaty to be in conformity with the Reichstag resolution. ${ }^{93} \mathrm{He}$ thought that the treaty would enable Germany to pursue a policy of self-determination with respect to the border nations. Later in March, however, Erzberger uttered his disappointment: The Lithuanians wanted independence, not a personal union with the German Empire. The military party, however, pressed for the latter solution, intending to confront the Reichstag with a fait accomplis. Erzberger spoke of a raiding of Lithuania that could not be tolerated. ${ }^{94} \mathrm{He}$ warned the chancellor that if the right of the Poles, Lithuanians and Courlanders to self-determination were not realized quickly, loyally and honestly, the Eastern peace would not be worth the paper on which it would be written. The main problem in the Eastern affairs were that the military authorities worked 'against the policy of the imperial chancellor'. ${ }^{95}$ Erzberger was briefly thinking of combining the consent of the Reichstag majority to the new war credits with a settlement of the Eastern questions in their interest. ${ }^{96}$ This idea, though, was not realized.

Meeting the chancellor on March 12, Fehrenbach put forward several demands in the name of the Majority Parties. The right to self-determination should guide Germany's Eastern Policy regarding the border nations. Any settlement would have to be approved by the Reichstag. The future Polish State should comprise the territory of Congress Poland, thus excluding any annexion of Polish territory by Germany. Poland would respect the German and Austrian-Hungarian borders and enter into an alliance with the Central Powers. ${ }^{97}$

This proposal had been made by Polish activist politicians and had been approved by the Regency Council in Warsaw. The Polish politicians had established contact with the Majority Parties expecting support by them and by the German government. ${ }^{98}$ The Majority

${ }^{93}$ Erzberger in the Reichstag, February 27, 1918, VR, Vol. 311, pp. 4217-4218.

${ }^{94}$ Committee of the Reichstag Majority, 11. 3. 1918, IA 1917/1918, II, Doc. 168, pp. $287-288$.

${ }^{95}$ Representatives of the Majority Parties meeting with the imperial chancellor, March 12, 1918, ibid., II, Doc. 170, pp. 303-304.

${ }^{96}$ Committee of the Reichstag Majority, March 11, 1918, ibid., II, Doc. 168, p. 285.

${ }^{97}$ Representatives of the Majority Parties meeting with the imperial chancellor, March 12, 1918, ibid., II, Doc. 170, p. 301.

${ }^{98}$ Conze, Polnische Nation, pp. $350 \mathrm{ff}$. 
Parties had drafted a declaration to be approved by the Main Committee of the Reichstag. ${ }^{99}$

Concerning Lithuania, the Reichstag Majority demanded the recognition of the Lithuanian independence as declared by the Taryba on December 11, 1917, and repeated on February 16, 1918. ${ }^{100}$ The question of the boundaries could be solved by Poland renouncing Vilnius if Białystok and the southern part of Suwalki were assigned to Poland.

With respect to Courland, where the Land Council had declared its intention to join the country to the German Empire and to offer the kaiser a grand-ducal crown, Fehrenbach stressed that the Reichstag would have to approve such a personal union with Germany. In addition, the Council of Courland had to be enlarged in order to be recognized as a representative body. On the other hand, the demand of the Council to unite all Baltic Provinces with Germany, including Livonia and Estonia, were to be regarded with severe reservations. ${ }^{101}$

Above all, Fehrenbach summed up, it was of the utmost importance to start negotiations with representatives of the emerging states in Berlin. Self-determination of the Eastern peoples proved to be the acid test of German honesty in the whole world. ${ }^{102}$

Replying to these well-defined demands, Hertling promised that the Council of Courland would soon be enlarged. The German government and the Kaiser intended to welcome the declaration of this Council. A definite decision as to the future of Courland could not yet be made. Hertling's remarks as to the Lithuanian question, however, proved to be quite vague. If the Taryba continued to uphold its declaration of December 1917, the independence of Lithuania would be recognized by Germany. Being under severe pressure by the Reichstag majority, Hertling complained in a meeting with the Kaiser, in the Lithuanian affairs he was misled by the Supreme Command. ${ }^{103}$

With respect to Poland, the initiative of the Majority Parties failed completely because Hertling threatened to resign. ${ }^{104}$ Even

${ }^{99}$ IA 1917/1918, II, Doc. 168, pp. 38, 291.

${ }^{100}$ Representatives of the Majority Parties meeting with the chancellor, March 12, 1918, ibid., II, Doc. 170, pp. 301-302.

101 Ibid., p. 302.

${ }^{102}$ Fehrenbach in the Committee of the Reichstag Majority reporting a discussion with Hertling, March 14, 1918, ibid., II, Doc. 172 a, p. 315.

103 Ibid., II, Doc. 171a, pp. 306-307.

${ }^{104}$ Fehrenbach in the Committee of the Reichstag Majority, March 13, 1918, ibid., II, Doc. 171, p. 305. In case the Reichstag parties maintained their position, 
Vice Chancellor Payer, a Progressive politician, saw no possibility of accepting such a far reaching move in foreign policy by the Reichstag. ${ }^{105}$ After intense discussions, the Centre and the Progressives were prepared to accept the government's refusal. Both of the parties adopted the peace treaty.

The Majority Social Democrats tried to keep in line with their policy of self-determination. ${ }^{106}$ Extremely disappointed, they were thinking of ending the cooperation with the government. ${ }^{107}$ Scheidemann called the situation desperate and asked if the Reichstag majority did not want to 'demonstrate strength of character', unless they wanted to 'appear before history as wretched puppets'. It was necessary 'to maintain the right to self-determination'. ${ }^{108}$

In the Reichstag plenary session, the Social Democrat, Dr David held the secession of the borderlands should have come into effect in a democratic way. He said the military party in Germany wanted to create a military colony in Lithuania. He called the resolution of the Council of Courland 'a business between the Prussian junkers and Baltic barons in agreement with a part of the German-Latvian bourgeoisie'. The German government should enable the Latvian population to vote on its future. ${ }^{109}$

In the end, the Majority Social Democrats, calling the treaty a peace of violence, abstained from voting. ${ }^{110}$ This abstension clearly demonstrated that the Reichstag Majority disagreed on the Eastern policy. On the other hand, the Social Democrats did not reject the treaty because it finished the state of war in the East.

Kühlmann regarded 'frontier rectifications' demanded by the Supreme Command to be inconceivable: Kühlmann (from Bucharest) to Foreign Office, 14. 3. 1918, ibid., Doc. 170, note 6, p. 301.

${ }^{105}$ Committee of the Reichstag Majority, March 18, 1918, IA 1917/1918, II, Doc. 174, pp. 326 ff.; Committee of the Reichstag Majority, March 20, 1918, ibid., Doc. 176, p. 335.

${ }^{106}$ Ritter, Staatskunst, IV, p. 147.

${ }^{107}$ Committee of the Reichstag Majority, March 18, 1918, IA 1917/1918, II, Doc. 174, p. 328-329, 331; March 20, 1918, Doc. 176 a, pp. 336-337, 341; P. Scheidemann, Memoiren eines Sozialdemokraten, II (Dresden, 1928), pp. 156-157.

${ }^{108}$ Committee of the Reichstag Majority, March 11, 1918, IA 1917/1918, II, Doc. 168 , p. 288.

109 Reichstag, session 142, VR, Vol. 311, p. 4431-4441, quotation pp. 4431, 4435, 4437.

${ }^{110}$ Meeting of the Social Democrats in Parliament, March 18 and 22, 1918, Reichstagsfraktion der Sozialdemokratie, II, Doc. 473, pp. 386, 392. Scheidemann in the Reichstag, session 145, March 22, 1918, VR, Vol. 311, p. 4536. 
The Independent Social Democrats scornfully rejected the treaty, calling it 'a peace of violence' and a 'victory for annexationism'. Haase protested, the Lithuanians were treated like 'vassals', and in Riga the 'the right to self-determination was faked outrageously'. ${ }^{111}$

There were several reasons for the Majority Parties' not rejecting the treaty. First, after the peace negotiations had failed, the position of the government and the Reichstag majority was severely weakened in opposing the Supreme Command. ${ }^{112}$ Second, all parties were relieved to have peace at least on one front. Third, the majority parties jointly hoped to improve the treaty of peace in the light of self-determination - by creating representative organs. ${ }^{113}$ Indeed, Article III of the Treaty of Brest-Litovsk said, 'Germany and Austria-Hungary intend to determine the future fate of the said territories in consultation with their inhabitants'. ${ }^{114}$

Trying to save what could be saved, the Majority Parties on Erzberger's initiative drafted a resolution demanding the right to selfdetermination for Poland, Lithuania and Courland, the building up of their states with local civil administration and the enlargement of the Land Councils. The agreements with the German Empire desired by the existing representative bodies should soon be concluded. The Resolution was adopted by the Reichstag. ${ }^{115}$ However, the meaning of self-determination was now significantly restricted. There was no more talk about a plebiscite or a democratically legitimated constitu-

${ }^{111}$ Reichstag, session 143, March 19, 1918, VR, Vol. 311, pp. 4473-4484 (Ledebour), quotation p. 4484; session 145, March 22, 1918, ibid., pp. 4540-4544 (Haase), quotation. pp. 4541, 4542.

112 Volkmann, Baltikumpolitik, p. 123.

${ }^{113}$ Meeting of the Social Democrats in Parliament, March 18, 1918 (quotation Scheidemann) and March 22, 1918, Reichstagsfraktion der Sozialdemokratie, II, pp. 386-392.

114 Treaty of Brest-Litovsk, Art. III, FBL, Doc. 390, p. 657. English text in: FRUS, 1918, Russia, I, Consul General at Moscow (Sumners) to the Secretary of State, March 30 and April 2, 1918. A more suitable translation than 'Germany and Austria-Hungary intend to determine the future fate of the said territories with the consent of their inhabitants' would be 'in contact with the inhabitants' resp. 'in consultation with' (the translation given in Wheeler-Bennett, Brest-Litovsk, p. 405, reads 'in agreement with their population'). The German version reads, 'Deutschland und Österreich beabsichtigten, das Schicksal Polens, Litauen und Kurlands 'im Benehmen mit deren Bevölkerung zu bestimmen'.

${ }^{115}$ Reichstag, session 145, 22. 3. 1918, VR, Vol. 311, p. 4570; Anlagen zu den Stenographischen Berichten, Vol. 324, p. 2154. 
ent body. ${ }^{116}$ Implicitly, the Councils in the occupied territories were considered as already being representative.

To put it in a positive way, the separation of the peoples of the Baltic provinces and Poland from Russian sovereignty could be called a first step to self-determination. ${ }^{117}$ In so far, there was an aspect of self-determination even in the treaty of Brest-Litovsk. The second step, however, a free decision of the peoples concerned about the future of their countries seemed to be postponed to an indefinite future. In Germany the 'military party', as President Wilson called it, prevailed.

Conclusion Accepting the Soviet proposal of a peace without annexation, based on the peoples' right to self-determination, and being under pressure by the Majority Parties, Chancellor Hertling publicly committed his government to respect the self-determination of Poles, Lithuanians and Courlanders. Apart from this declaration, the government wished to join the emerging states to Germany, albeit, not by means of annexion. The Supreme Command, led by Hindenburg and Ludendorff, completely rejected self-determination and tried to put through its policy of military expansion and annexion in the occupied territories.

Secretary of State Kühlmann, attempting to reconcile all these different positions, made tactical use of the principle of self-determination. In Brest-Litovsk, however, he failed to secure the Soviet approval of the Councils of the emerging states.

German Eastern Policy was further challenged by the demands of self-determination as expressed by President Wilson and Prime Minister Lloyd George. Both political leaders presented a clear-cut conception of self-determination, implying government with consent of the governed and a settlement of territorial questions in the interest of the populations concerned. Hertling, however, only formally approved these principles and declared the territorial questions to be solved bilaterally.

The Majority Parties in the Reichstag were prepared to meet the Anglo-Saxon concept of self-determination and to accept most of the

${ }^{116}$ Volkmann, Baltikumpolitik, p. 130-131. Main Committee, March 20 1918, HA, IV, Doc. 220, p. 2063.

117 On March 15, 1918, Courland was recognized as a 'free and independent Duchy', and on March 23, after Lithuanian delegates had been provided with visa to Berlin, Lithuania was recognized 'as a free and independent State'. See Ursachen und Folgen. Vom deutschen Zusammenbruch 1918 und 1945 bis zur staatlichen Neuordnung Deutschlands in der Gegenwart (Berlin, n. d.), Doc. 295, p. 181; Doc. 295a, p. 182. 
Fourteen Points. They tried to secure a possibility for the peoples of the emerging states to express their own will. The chance to influence affairs in this way melt away when the Reichstag majority adopted the German-Soviet peace treaty, while only the Social Democrats abstained from voting. Parliament and the government were rapidly losing power with regard to the Supreme Command after the Soviet withdrawal from the peace negotiations.

Thus, the separation of the peoples of the Baltic provinces and of Poland from Russian sovereignty could be considered a first step towards self-determination. The second step, however, a free decision of the peoples about the future of their countries, seemed - in March 1918 - to be postponed to an indefinite future.

\section{APSISPRENDIMAS 1918 M. PRADŽIOJE IR VOKIEČIŲ REAKCIJA}

Santrauka

\section{CHRISTIAN RUST}

Vokietijos kancleris Hertlingas, priimdamas tautų apsisprendimo teise gristą Sovietų Sajungos siūlymą dèl taikos be aneksijos ir atsižvelgdamas i primygtinị Daugumos partijų reikalavimą, viešai ipareigojo savo vyriausybę gerbti lenkų, lietuvių ir kuršiu apsisprendimo teisę. Nors tai buvo deklaruota, vyriausybe puoselejo tikslus prijungti besikuriančias naujas valstybes prie Vokietijos, tačiau tik ne aneksijos būdu. Kariuomenès generalinis štabas, vadovaujamas Hindenburgo ir Ludendorffo, visiškai atmetė apsisprendimo galimybę ir bandè prastumti karinès ekspansijos ir aneksijos politiką okupuotų teritorijų atžvilgiu.

Valstybès sekretorius Kühlmannas, siekdamas taikingai suderinti šias skirtingas pozicijas, taktiškai pritaikè apsisprendimo principą. Tačiau Brest-Litovske jam nepavyko gauti Sovietų pritarimo dèl naujų valstybių Tarybų.

Vokietijos vykdoma Rytu politika ir toliau buvo ginčijama prezidentui Wilsonui ir Ministrui pirmininkui Lloydui George ui reikalaujant tautų apsisprendimo teisès. Abu politiniai lyderiai pateikè aiškią tautų apsisprendimo teisès koncepciją, numatančią galimybę vadovauti vadovaujamuju sutikimu, ir teritorinių klausimų išsprendimą atsižvelgiant i gyventojų interesus. Tačiau Hertlingas pritare šiems principams tik formaliai ir paskelbè, kad teritoriniai klausimai turi būti sprendžiami dvišaliu susitarimu.

Reichstago Daugumos partijos buvo pasirengusios pritarti anglosaksu koncepcijai dèl tautu apsisprendimo teisès ir priimti didesnę dalį „Keturiolikos punktų“. Jais buvo siekiama užtikrinti galimybę besiformuojančių naujų valstybių tautoms išreikšti savo pačiu valią. Galimybè pakreipti klausimus tokia linkme išgaravo, kai Reichstago dauguma prièmė Vokietijos ir Sovietų Sajungos taikos sutartí, nebalsavo tik socialdemokratai. Parlamento ir vyriausybès valdžia Generaliniam štabui èmè sparčiai silpnèti po to, kai Sovietų Sajunga pasitraukè iš taikos derybų.

Taigi Baltijos provincijų ir Lenkijos tautų atsisakymas pavaldumo Rusijai galëjo būti laikomas pirmuoju žingsniu, žengtu tautų apsisprendimo teisès link. Vis dèlto antrasis žingsnis, kai tautos mėgino laisvai nulemti savo šalių ateiti 1918 m. kovą, nusikèlè ì neapibrèžtą ateitị. 